\title{
Biotic potential and reproductive parameters of Spodoptera cosmioides (Walker) (Lepidoptera: Noctuidae) in the laboratory
}

\author{
A. Specht ${ }^{a *}$ and V. F. Roque-Specht ${ }^{b}$ \\ ${ }^{a}$ Embrapa Cerrados, BR 020, Km 18, CP 08223, CEP 73310-970, Planaltina, DF, Brasil \\ ${ }^{\text {b} F a c u l d a d e ~ U n B ~ P l a n a l t i n a, ~ U n i v e r s i d a d e ~ d e ~ B r a s i ́ l i a ~-~ U n B, ~ A ́ r e a ~ U n i v e r s i t a ́ r i a ~ 1, ~ V i l a ~ N o s s a ~ S e n h o r a ~ d e ~ F a ́ t i m a, ~}$ \\ CEP 73345-010, Planaltina, DF, Brasil \\ *e-mail: alexandre.specht@embrapa.br
}

Received: August 27, 2017 - Accepted: December 26, 2017 - Distributed: August 31, 2019

(With 6 figures)

\begin{abstract}
In this study we evaluate the biotic potential and reproductive parameters of Spodoptera cosmioides (Walker, 1858) under controlled conditions $\left(25 \pm 1{ }^{\circ} \mathrm{C}, 70 \pm 10 \% \mathrm{RH}\right.$ and 14 hour photophase). Females, on average, (14.433 days) did not live significantly longer than their male counterparts (13.100 days). The mean durations of the pre-oviposition, oviposition and post-oviposition periods were $2.767,10.600$ and 1.067 days, respectively. The mean fecundity of females was 5,073.533 eggs and the mean fertility was 5,021.027 larvae. On average, females copulated 1.167 times. Fecundity was positively correlated with the number of copulations $(\mathrm{r}=0.583, \mathrm{P}<0.001)$. The number of copulations, however, was negatively correlated whit the duration of the pre-oviposition $(\mathrm{r}=-0.560, \mathrm{P}=0.007)$ and oviposition $(\mathrm{r}=-0.479, \mathrm{P}=0.048)$ periods, and overall longevity $(\mathrm{r}=-0.512, \mathrm{P}=0.031)$. The biotic potential was estimated at $6.547 \times 10^{21}$ individuals/female/year. The net reproductive rate (Ro) was 2,193.722 times per generation and the mean generation time (T) was 46.407 days. The intrinsic rate of increase (rm) was 0.166 , with a finite rate of increase $(\lambda)$ of 1.180 , per week.
\end{abstract}

Keywords: armyworm, development, fecundity, reproduction, spermatophore.

\section{Potencial biótico e parâmetros reprodutivos de Spodoptera cosmioides (Walker) (Lepidoptera: Noctuidae) em laboratório}

\begin{abstract}
Resumo
Neste estudo avaliamos o potencial biótico e parâmetros reprodutivos de Spodoptera cosmioides (Walker, 1858) em condições controladas $\left(25 \pm 1{ }^{\circ} \mathrm{C}, 70 \pm 10 \%\right.$ UR e 14 horas de fotofase). Em média, as fêmeas (14,433 dias) não viveram significativamente mais do que os machos (13,100 dias). A duração média dos períodos de pre-oviposição, oviposição e pós-oviposição foram 2,767; 10,600 e 1,067 dias, respectivamente. A fecundidade média das fêmeas foi de 5.073,533 ovos e a fertilidade média foi de 5.021,027 larvas. Em média, as fêmeas copularam 1,167 vezes. A fecundidade correlacionou-se positivamente com o número de cópulas $(\mathrm{r}=0,583 ; \mathrm{P}<0,001)$. Entretanto, o número de cópulas correlacionou-se negativamente com a duração dos períodos de pré-oviposição $(r=-0,560 ; P=0,007)$, oviposição $(\mathrm{r}=-0,479 ; \mathrm{P}=0 ; 048)$ e a longevidade $(\mathrm{r}=-0,512 ; \mathrm{P}=0,031)$. O potencial biótico foi estimado em $6,547 \times 10^{21}$ indivíduos/fêmea/ano. A taxa líquida de reprodução (Ro) foi de $2.193,722$ vezes por geração e o tempo médio de cada geração (T) foi de 46,407 dias. A taxa intrínseca de crescimento (rm) foi 0,166, com uma taxa finita de aumento $(\lambda)$ de 1,180 , por semana.
\end{abstract}

Palavras-chave: lagarta militar, desenvolvimento, fecundidade, reprodução, spermatóforo.

\section{Introduction}

The genus Spodoptera Guenée, 1852 (Lepidoptera: Noctuidae) or "armyworms" is one of the most important groups of owlet moth pests around the world. Spodoptera cosmioides (Walker, 1858) occurs from Panama to southern South America (Pogue, 2002) and was considered a synonym of S. latifascia (Walker, 1856) (Poole, 1989) until Silvain and Lalanne-Cassou (1997).
Studies on the host-plant associations, temporal and spatial distribution, morphology, and biology of $S$. cosmioides have highlighted its importance as a pest of several crops, its low susceptibility to $B t$ protenis and to the entomopathogenic fungus Metarhizium rileyi (Farlow) Samson (e.g., Specht and Corseuil, 2002; Bavaresco et al., 2002, 2003, 2004; Specht et al., 2005; Zenker et al., 
2007, 2010; Fronza et al., 2011; Bergamasco et al., 2013; Cabezas et al., 2013; Fronza et al., 2013; Bernardi et al., 2014; Specht and Roque-Specht, 2016).

This study complements a previous publication on the immatures of S. cosmioides (Specht and Roque-Specht, 2016) and is part of a project where the main species of armyworms are being studied under identical controlled conditions. These studies aim to compare the biology of these species, establish biological patterns and differences. Thus, in this work we compare the biological data of $S$. cosmioides with three species already studied in same conditions: S. albula (Walker, 1857), S. eridania (Stoll, 1782) and S. dolichos (Fabricius, 1794) (Montezano et al., 2013a, b, 2014a, b, 2015, 2016) and other works about S. cosmioides (Santos et al., 1980; Habib et al., 1983; Bavaresco et al., 2002, 2003, 2004; Zenker et al., 2007; Cabezas et al., 2013).

\section{Material and Methods}

The experiments were carried out in a climate-controlled room $\left(25 \pm 1^{\circ} \mathrm{C}, 70 \pm 10 \% \mathrm{RH}\right.$ and a 14 hour photophase). Observations were carried out daily. The insects used in the experiment came from a first generation of caterpillars collected from Fevillea cordifolia Linn. (Cucurbitaceae) in the city of Planaltina, Federal District, Brazil (15'36'16.85'S; $47^{\circ} 43^{\prime} 06.57^{\prime \prime} \mathrm{W}, 1020 \mathrm{~m}$ a.s.l) (Specht and Roque-Specht, 2016).

To avoid the effects of variations in the pupal weight on the reproductive characteristics of the adult (Tisdale and Sappington, 2001; Specht et al., 2016), and also to standardize the procedure and avoid hurting the insects while their pupae was still soft, all pupae were weighed on the second day after metamorphosis, and only adult females from pupae weighing between 0.632 and $0.674 \mathrm{~g}$, and adult males from pupae weighing between 0.591 and $0.648 \mathrm{~g}$, were used in the experiment. Likewise, to avoid the effects of the age of the adults on their capacity to copulate (Kehat and Gordon, 1975; Rogers and Marti Junior, 1994), couples were formed with adults that emerged on the same date.

Adults were kept in pairs $(\mathrm{n}=30)$ within cylindrical plastic containers ( $10 \mathrm{~cm}$ in diameter and $15 \mathrm{~cm}$ high) with long filter paper strips attached to stimulate oviposition. The tops of the containers were closed with plastic film and the bottoms were closed with Petri dishes ( $10.5 \mathrm{~cm}$ diameter) lined with filter paper. The adult diet was composed of honey (10g), sorbic acid (p.a. - Sigma-Aldrich) (1g), methylparaben (p.a. - Sigma-Aldrich) (1g), sucrose (p.a. Merck) (60g), and distilled water (1000 mL) (Hoffmann-Campo et al., 1985). All components were dissolved in distilled water and the resulting solution was kept under refrigeration $\left(7^{\circ} \mathrm{C}\right)$ until it was used. Pilsen beer was added to the solution daily in the proportion of 1:4, beer/diet, and made available to the insects in a $5 \mathrm{~cm}$ Petri dish lined with cotton wool. Additionally, autoclaved water was provided in another $5 \mathrm{~cm}$ cotton-lined Petri dish. Containers were examined daily to record adult survival and to remove the eggs and to count their numbers. Dead females were dissected to determine the number of spermatophores they had received from males during copulation.

We count the realized fecundity (only eggs laid per female), fertility (number of hatched larvae per female) and longevity for females and males. The duration of the pre-oviposition, post-oviposition and oviposition periods were determined considering the pairing, in the day of adult emergence. To estimate fertility, we determined the viability of 87 egg masses $(\mathrm{N}=9,563$ eggs $)$ taken from four mated couples, including the first and the last egg masses. Each egg cluster was placed in a Petri dish, which was lined with filter paper moistened with distilled water until larval eclosion. All evaluated egg masses were from females that had at least one spermatophore in the bursa copulatrix. The determination of the presence of spermatophores was made on dead females to confirm that they had been fertilized during the experiment.

All biological parameters were analyzed using descriptive statistics. The fecundity and longevity of both sexes and the duration of pre-oviposition, oviposition and post-oviposition periods were correlated (Pearson Product Moment Correlation) with the number of matings of each couple. Owing to the high correlation of the parameters with respect to the number of matings, only the overall averages of longevity were compared using the t-test assuming unequal variances, at a significance level of $5 \%$. Between-couple comparisons of the pre-oviposition, oviposition, longevity and fecundity were performed using ANOVA, with the number of spermatophores as factors, and the means were separated by Tukey's test at $5 \%$ probability in SPSS program version 10.0.

After gathering the biological parameters, the Biotic Potential (BP) was calculated considering the resistance of the environment as being null. We used the equation described in Silveira Neto et al. (1976), BP $=(\mathrm{sr} * \mathrm{~d})$ ${ }^{n}$ - er, where: (sr) sex ratio is number of females divided by number of females plus number of males; (d) viable individuals per female consisting of the number of eggs per female (or fecundity) multiplied by total survival; (n) number of generations per year or 365 days divided by the total lifespan; and (er) environmental resistance, in this case considered null.

The biotic potential and fertility life table were developed using data from the immature stages of $S$. cosmioides (survival and duration of eggs, larvae, prepupae and pupae) reared in accordance with the methodology of Specht and Roque-Specht (2016). The data on the table is graphically presented by plotting the probability of survival values at the midpoint of each time interval, (survival rate - $1 \mathrm{x}$ ), and the total number of eggs per female, per week, from which females hatched (specific fertility - mx).

The following parameters were calculated using the formulas in Silveira Neto et al., (1976): net reproductive rate (Ro - ratio between the number of females in two successive generations); mean generation time ( $\mathrm{T}$ - mean number of days from the birth of the parents to the birth of 
offspring); daily intrinsic rate of increase (rm); and daily finite rate of increase $(\lambda)$.

\section{Results}

Table 1 presents the longevity of 30 couples of $S$. cosmioides; the longevity of females and males separately; the mean length of pre-oviposition, oviposition, post-oviposition and mean fecundity. Using the data of egg viability $(98,966 \%)$ from $5,073.533$ eggs, the mean fertility was 5,021.027 larvae per female.

The average number of copulations per $S$. cosmioides female was 1.167 times, while four $(13.333 \%)$ females did not copulate, fifteen copulated only once $(50.000 \%)$, seven copulated twice $(23.333 \%)$ and four copulated three times $(13.333 \%)$. The fecundity was positively correlated with the number of copulations $(\mathrm{r}=0.583, \mathrm{P}<0.001)$. However, the number of copulations was negatively correlated with the duration of the pre-oviposition period $(\mathrm{r}=-0.560$, $\mathrm{P}=0.007)$, oviposition period $(-0.479, \mathrm{P}=0.048)$ and longevity $(\mathrm{r}=-0.512, \mathrm{P}=0.003)$.

The mean daily number of eggs from unfertilized females was smaller than from females that were fertilized one or more times (Figure 1). The pre- and oviposition periods were significantly longer in females that were not fertilized (Figures 2, 3). Such differences were responsible for the significantly increased longevity of unfertilized females with respect to fertilized females (Figure 4). Fecundity was positively affected by the number of matings, since unfertilized females oviposited less than half the number of eggs produced by fertilized females, with significant differences between unfertilized females, and those that had been fertilized once and twice (Figure 5).

The biotic potential, calculated from the equation $\mathrm{BP}=(\mathrm{sr} * \mathrm{~d})^{\mathrm{n}}-$ er $\mathrm{BP}=(0.505 \times 4,535.685)^{6.493}-0$, was $6.547 \times 10^{21}$ individuals per female per year. The calculation of the sexual ratio $(0.505)$ was based on the 137 immature females and 134 immature males that reached the pupal stage. On average, each female oviposited 5,073.533 eggs, and the overall survival was $89.399 \%$ (see Specht and Roque Specht, 2016), resulting in 4,535.687 viable individuals per female/period. The average duration of the life cycle (egg to adult dead) was 54.828 days [longevity and immature period of Specht and Roque-Specht (2016)], corresponding to 6.493 generations per year (n), considering the environmental resistance as null.

The maximum rate of population growth occurred between days 42 and 46, during the 6/7th week of life,

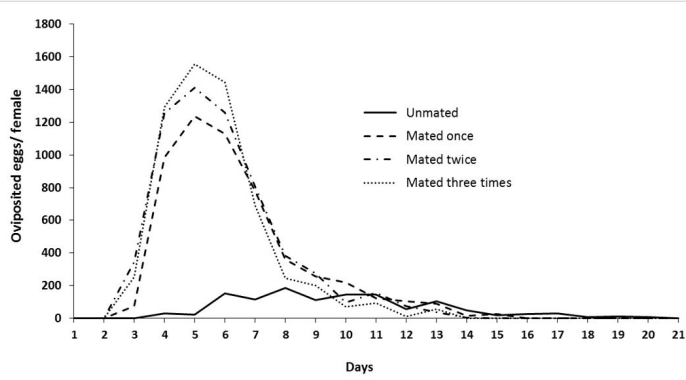

Figure 1. Daily mean number of eggs oviposited by Spodoptera cosmioides, individuals that did not mate $(n=4)$, mated once $(n=15)$, twice $(n=7)$ or three times $(\mathrm{n}=4)$. One couple per cage at $25 \pm 1{ }^{\circ} \mathrm{C}, 70 \pm 10 \% \mathrm{RH}$ and a 14 hour photophase.

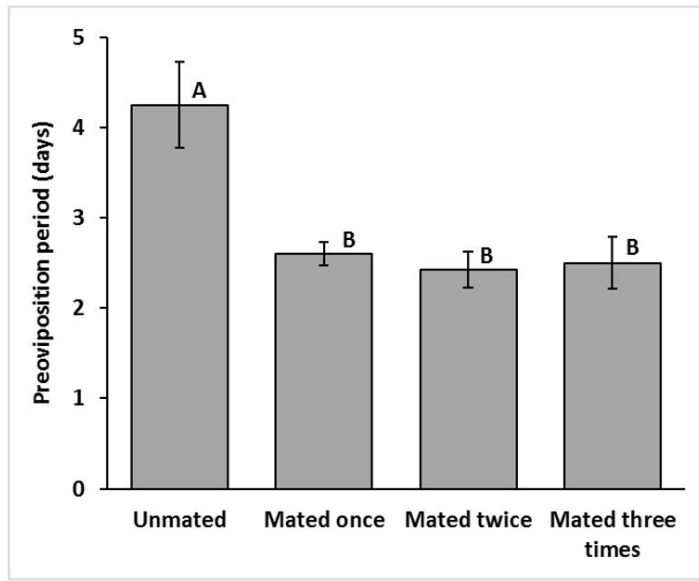

Figure 2. Pre-oviposition period of Spodoptera cosmioides, individuals that did not mate $(n=4)$, mated once $(n=15)$, twice $(n=7)$ or three times $(n=4)$. One couple per cage at $25 \pm 1{ }^{\circ} \mathrm{C}, 70 \pm 10 \% \mathrm{RH}$ and a 14 hour photophase. Means followed by the same letter are not statistically different from each other by Tukey test, at $5 \%$ probability.

Table 1. Longevity, pre-ovipotition, oviposition, post-oviposition periods and fecundity of (mean number eggs laid) Spodoptera cosmioides (30 couples), under controlled conditions $\left(25 \pm 1^{\circ} \mathrm{C}, 70 \pm 10 \% \mathrm{RH}\right.$ and a 14 hour photophase).

\begin{tabular}{ccccc}
\hline Sex & Biological parameter & Mean & Standard Deviation & Range \\
\hline Both & Longevity (days) & 13.767 & 2.794 & $9-21$ \\
Female & Longevity (days) & 14.433 & 2.849 & $9-21$ \\
& Pre-oviposition (days) & 2.767 & 0.817 & $2-5$ \\
& Oviposition (days) & 10.600 & 2.634 & $5-17$ \\
& Post-oviposition (days) & 1.067 & 0.740 & $0-2$ \\
& Fecundity (eggs) & $5,073.533$ & $1,952.486$ & $413-8,593$ \\
Male & Longevity (days) ns & 13.100 & 2.618 & $9-17$ \\
\hline
\end{tabular}

Comparisons of male and female mean longevity using a Student $t$-test, considering different variances, at $5 \%$ level of significance (ns - p = 0.064). 


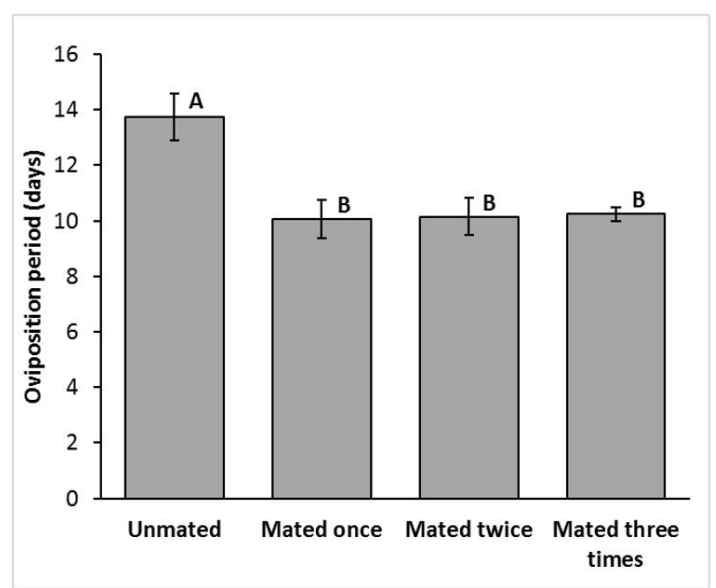

Figure 3. Oviposition period of Spodoptera cosmioides, individuals that did not mate $(n=4)$, mated once $(n=15)$, twice $(n=7)$ or three times $(n=4)$. One couple per cage at $25 \pm 1{ }^{\circ} \mathrm{C}, 70 \pm 10 \% \mathrm{RH}$ and a 14 hour photophase. Means followed by the same letter are not statistically different from each other by Tukey test, at 5\% probability.

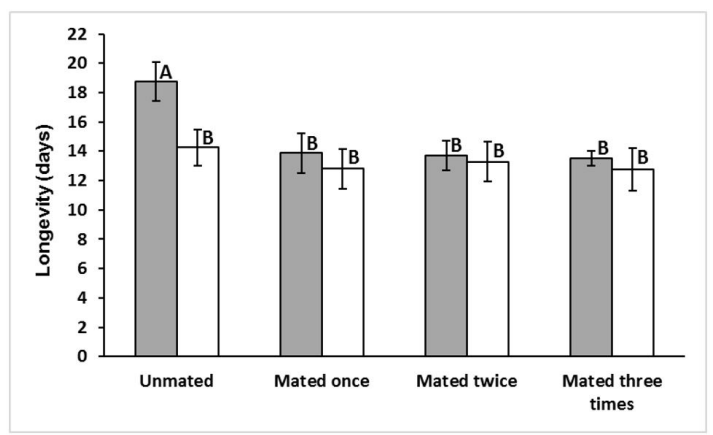

Figure 4. Longevity of Spodoptera cosmioides, females (dark bars) and males (empty bars), individuals that did not mate $(n=4)$, mated once $(n=15)$, twice $(n=7)$ or three times $(\mathrm{n}=4)$. One couple per cage at $25 \pm 1{ }^{\circ} \mathrm{C}, 70 \pm 10 \% \mathrm{RH}$ and a 14 hour photophase. Means followed by the same letter are not statistically different from each other by Tukey test, at $5 \%$ probability.

represented by the intersection of the specific survival and fecundity lines (Figure 6). This rate is shifted towards the beginning of the adult phase, especially driven by the higher fertility and lower mortality of immature individuals, soon after emergence.

The net reproductive rate (Ro) was 2,193.722 females per generation, the mean generation time (T) was 46.407 days, the daily intrinsic rate of increase (rm) was 0.166 and the daily finite rate of increase $(\lambda)$ was $=1.180$.

\section{Discussion}

The total life cycle of $S$. cosmioides (54.828 days) considering the data of immatures (Specht and Roque Specht, 2016; 41.061) and the longevity of adults (Table 1)

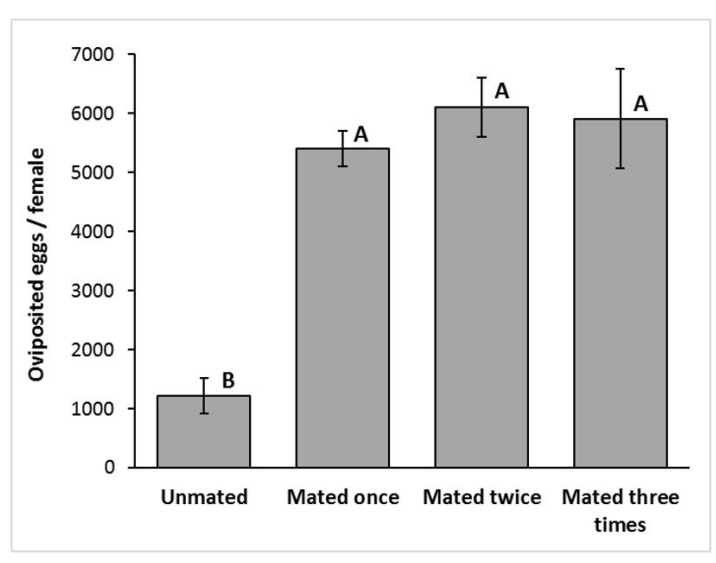

Figure 5. Mean number of eggs laid by Spodoptera cosmioides, individuals that did not mate $(n=4)$, mated once $(n=15)$, twice $(n=7)$ or three times $(\mathrm{n}=4)$. One couple per cage at $25 \pm 1{ }^{\circ} \mathrm{C}, 70 \pm 10 \% \mathrm{RH}$ and a 14 hour photophase. Means followed by the same letter are not statistically different from each other by Tukey test, at $5 \%$ probability.

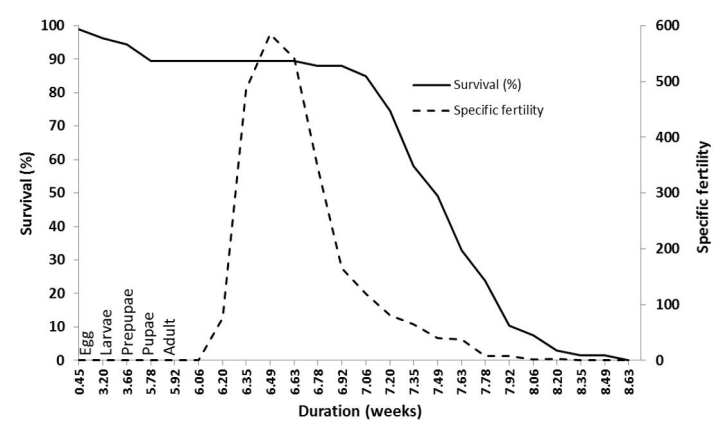

Figure 6. Relation between specific fertility $(\mathrm{mx})$ and survival rate (1x) of Spodoptera cosmioides reared on an artificial diet at $25 \pm 1{ }^{\circ} \mathrm{C}, 70 \pm 10 \% \mathrm{RH}$ and a 14 hour photophase.

is consistent with previous findings for same species when reared under similar environmental conditions and artificial diet (Bavaresco et al., 2004). The total duration of the life-cycle of $S$. cosmioides (male forewing length $16-20 \mathrm{~mm}$ ) in this study was almost ten days less than reported for $S$. dolichos (Fabricius, 1794) (male forewing length 18-21mm) (Montezano et al., 2015, 2016), which is a little larger in size than $S$. cosmioides. However, $S$. cosmioides lived much longer than smaller species raised under the same conditions, such as $S$. albula (male forewing length $10-14 \mathrm{~mm}$ ) and $S$. eridania (male forewing length 13-15mm) (Montezano et al., 2013a, b, 2014a, b). Similarly, the life cycle of $S$. cosmioides was slightly longer than that of $S$. frugiperda (J.E. Smith, 1797) (male forewing length $10-15 \mathrm{~mm}$ ) in similar conditions of diet and temperature (Busato et al., 2006).

The negative correlation between the number of matings (specially with mated and non-mated females) 
versus pre-oviposition, oviposition periods and female longevity (Figures 2-4), reinforces the need to account the spermatophore number in reproductive studies (e.g., Rogers and Marti Junior, 1997; Montezano et al., 2013b, 2014a, 2015).

The average longevity of $S$. cosmioides adults in this study (Table 1), when compared with the duration of the immature stages (41.061 days) (Specht and Roque-Specht, 2016), corresponds to $25.104 \%$, or more than one-fourth of their entire life cycle. These results are similar to those obtained for S. albula (28.324\%) (Montezano et al., 2013a, 2014a) and S. eridania (24.495\%) (Montezano et al., 2013b, $2014 b$ ) and above those obtained for S. dolichos (20.507\%) (Montezano et al., 2015, 2016) under the same conditions.

The average number of matings of $S$. cosmiodes females is similar to what was described for $S$. albula, S. dolichos and S. eridania (Montezano et al., 2013b, 2014a, 2015) reared under the same conditions. The absence of mating in some $S$. cosmioides couples owes to the fact that only one pair was maintained in each cage. Insects that are maintained in pairs sometimes do not mate (Murúa et al., 2008; Montezano et al., 2013b, 2014a, 2015), whereas insects that are maintained in larger mixed groups of males and females often do (Milano et al., 2008; Specht et al., 2016). Thus, it was expected that a greater number of $S$. cosmioides individuals per cage would also increase the number of copulations and decrease the time between generations.

The positive correlation between the number of copulations and fecundity obtained in this study, and which was also observed in S. albula, S. dolichos and S. eridania (Montezano et al., 2013b, 2014a, 2015), reinforces the relationship between the number of copulations and population numbers. In this way, the number copulations positively influence two important parameters in the development of the adult: fecundity (and fertility by extension) and decrease in time between generations.

The pre-oviposition period (Table 1) of S. cosmioides, especially in fertilized females (Figure 2), indicates that this species, as it is the case of $S$. dolichos (Montezano et al., 2015), spends at least one more day in it than S. albula and S. eridania (Montezano et al., 2013b, 2014b) under the same conditions. Ultimately, the sexual maturity of $S$. cosmioides occurs soon after emergence, as in other representatives of Spodoptera (e.g. Habib et al., 1983; Tisdale and Sappington, 2001; Busato et al., 2006; Montezano et al., 2013a, 2014b, 2015). Our results indicate that the initial fertilization period of $S$. cosmioides must be between the second and third days after emergence. However, the onset of oviposition, at least in the first days after emergence, is conditioned by the occurrence of the first mating, as described for S. exigua (Rogers and Marti Junior, 1994), S. eridania (Montezano et al., 2013b), S. albula (Montezano et al., 2014a) and S. dolichos (Montezano et al., 2016).

The fertility of $S$. cosmioides was highly variable, with approximately 5,000 eggs per female (Table 1), when considering adults from pupae of average weight.
These results are similar to those obtained for the same species reared under similar conditions of temperature and the following diet: similar larval diet and adults fed 10\% honey solution (4,844.4 eggs/female) (Bavaresco et al., 2004). Fertility in this species was much higher than in S. albula and S. eridania reared under the same conditions (Montezano et al., 2013b, 2014a). It was also higher than observed in $S$. dolichos reared under the same conditions (Montezano et al., 2015) and S. frugiperda reared under similar conditions of temperature and diet (Busato et al., 2006), and S. littoralis (male forewing length $12-16 \mathrm{~mm}$ (Sorour et al., 2011).

The fertility of females was influenced by fertilization (Figure 5), consistent with observations on other species of Spodoptera reared under the same conditions (Montezano et al., 2013a, 2014b, 2015). It is worthy highlighting that $S$. cosmioides females that mated one or more times $(5,667.083 \pm 1,277.452)$ laid 4.662 times more eggs than females that did not mate $(1,215.501 \pm 594.383)$.

The viability of eggs $(99.000 \%)$ of females that had one or two spermatophores was high. This percentage agrees with the $94.500,97.800 \%$ and 97,500 observed for fertilized females of S. albula, S. eridania and S. dolichos, respectively, under the same conditions (Montezano et al., 2013b, 2014a, 2015). This observation agrees with studies on representatives of the genus Spodoptera, for which it has been demonstrated that multiple matings are positively correlated with reproductive capacity and fertility (Kehat and Gordon, 1975; Sadek, 2001; Sadek and Anderson, 2007; Milano et al., 2008; Specht et al., 2016).

Despite the high fecundity and fertility (Table 1), the biotic potential $\left(6.547 \times 10^{21}\right.$ individuals/female/year) of $S$. cosmioides was comparable to that observed for $S$. albula and $S$. eridania; and it was higher than that observed for $S$. dolichos, under the same conditions (Montezano et al., 2013a, 2014b, 2015). This value was positively influenced by the high value of net reproductive rate (Ro) 2,193.722 females per generation, but negatively influenced by the long duration of the life cycle, represented by a mean generation time (T) of 46.407 days. This relationship results in that the daily intrinsic rate of increase $(\mathrm{rm}=0.166)$ and the daily finite rate of increase $(\lambda=1.180)$ were similar to those observed for $S$. albula and $S$. eridania under the same conditions (Montezano et al., 2013a, 2014b).

Our results, when compared with previous studies on other species of the genus (e.g., Busato et al., 2006; Montezano et al., 2013a, b, 2014a, b, 2015, 2016), indicate that larger Spodoptera species take longer to develop and have higher fecundity. This means that the longer developmental period of larger species such as $S$. cosmioides (present study, Bavaresco et al., 2004) and S. dolichos (Montezano et al., 2015, 2016) would be compensated by an increase in fecundity, which does not happen in smaller species, such as S. albula (Montezano et al., 2013a), S. eridania (Montezano et al., 2014b) and S. frugiperda (Busato et al., 2006).

The maximum rate of population increases of $S$. cosmioides (Figure 6) happens in the beginning of 
the adult stage, especially driven by the higher fertility and low mortality of the immature individuals shortly after emergence. These observations are similar to those reported in other studies conducted with representatives of Spodoptera, in which the highest fertility values were observed during the first days of the adult life (Kehat and Gordon, 1975; Sadek, 2001; Bavaresco et al., 2004; Murúa and Virla, 2004; Busato et al., 2006; Montezano et al., 2013b, 2014a, 2015).

The data presented in this study demonstrate that a reduction, or delay, in the number of matings negatively influences the population parameters of $S$. cosmioides. These results highlight the relevance of studies on the identification and use of pheromones of $S$. cosmioides (e.g. Teixeira et al., 1989, 1993; Silvain and Lalanne-Cassou, 1997) to delay or prevent mating in nature, or as a mating disruption agent (Carde and Minks, 1995), as a strategy for the integrated management of this pest species.

\section{Acknowledgements}

To Conselho Nacional de Desenvolvimento Cientifico e Tecnológico $(\mathrm{CNPq})$ for granting to the first author (process 306601/2016-8) and for financial assistance (process 482627/2010-7). To Instituto Chico Mendes (ICMBio) - Ministério do Meio Ambiente do Brasil Authorization for scientific activities SISBIO 38547/(1-6).

\section{References}

BAVARESCO, A., GARCIA, M.S., GRÜTZMACHER, A.D., FORESTI, J. and RINGENBERG, R., 2002. Biologia e exigências térmicas de Spodoptera cosmioides (Walk.) (Lepidoptera: Noctuidae). Neotropical Entomology, vol. 31, no. 1, pp. 49-54. http://dx.doi.org/10.1590/S1519-566X2002000100007.

BAVARESCO, A., GARCIA, M.S., GRÜTZMACHER, A.D., FORESTI, J. and RINGENBERG, R., 2003. Biologia comparada de Spodoptera cosmioides (Walk.) (Lepidoptera: Noctuidae) em cebola, mamona, soja e feijão. Ciência Rural, vol. 33, no. 6, pp. 993-998. http://dx.doi.org/10.1590/S0103-84782003000600001.

BAVARESCO, A., GARCIA, M.S., GRÜTZMACHER, A.D., RINGENBERG, R. and FORESTI, J., 2004. Adequação de uma dieta artificial para a criação de Spodoptera cosmioides (Walk.) (Lepidoptera: Noctuidae) em laboratório. Neotropical Entomology, vol. 33, no. 2, pp. 155-161. http://dx.doi.org/10.1590/ S1519-566X2004000200005.

BERGAMASCO, V.B., MENDES, D.R., FERNANDES, O.A., DESIDÉRIO, J.A. and LEMOS, M.V., 2013. Bacillus thuringiensis Cry1 Ia10 and Vip3Aa protein interactions and their toxicity in Spodoptera spp. (Lepidoptera). Journal of Invertebrate Pathology, vol. 112, no. 2, pp. 152-158. http://dx.doi.org/10.1016/j. jip.2012.11.011. PMid:23220241.

BERNARDI, O., SORGATTO, R.J., BARBOSA, A.D., DOMINGUES, F.A., DOURADO, P.M., CARVALHO, R.A., MARTINELLI, S., HEAD, G.P. and OMOTO, C., 2014. Low susceptibility of Spodoptera cosmioides, Spodoptera eridania and Spodoptera frugiperda (Lepidoptera: Noctuidae) to geneticallymodified soybean expressing Cry1Ac protein. Crop Protection
(Guildford, Surrey), vol. 58, pp. 33-40. http://dx.doi.org/10.1016/j. cropro.2014.01.001.

BUSATO, G.R., GARCIA, M.S., LOECK, A.E., ZART, M., NUNES, A.M., BERNARDI, O. and ANDERSSON, F.S., 2006. Adequação de uma dieta artificial para biótipos "milho" e "arroz" de Spodoptera frugiperda (Lepidoptera: Noctuidae). Bragantia, vol. 65, no. 2, pp. 317-323. http://dx.doi.org/10.1590/ S0006-87052006000200014.

CABEZAS, M.F., NAVA, D.E., GEISSLER, L.O., MELO, M., GARCIA, M.S. and KRÜGER, R., 2013. Development and leaf consumption by Spodoptera cosmioides (Walker) (Lepidoptera: Noctuidae) reared on leaves of Agroenergy Crops. Neotropical Entomology, vol. 42, no. 6, pp. 588-594. http://dx.doi.org/10.1007/ s13744-013-0169-6. PMid:27193276.

CARDÉ, R.T. and MINKS, A.K., 1995. Control of moth pests by mating disruption: successes and constraints. Annual Review of Entomology, vol. 40, no. 1, pp. 559-585. http://dx.doi.org/10.1146/ annurev.en.40.010195.003015.

FRONZA, E., MIGUES, I., SPECHT, A., BARROS, N.M. and HEINZEN, H., 2013. Identification of $\alpha$-tocopherol and $\alpha$-tocopheryl acetate from the cuticle of soybean pods armyworm (Spodoptera cosmioides). Natural Product Research, vol. 27, no. 19, pp. 1808-1811. http://dx.doi.org/10.1080/14786419.2012.76 3125. PMid:23356865.

FRONZA, E., SPECHT, A. and CORSEUIL, E., 2011. Butterflies and moths (Insecta: Lepidoptera) associated with erva-mate, the South American holly (Ilex paraguariensis St. Hil), in Rio Grande do Sul, Brazil. Check List, vol. 7, no. 4, pp. 496-504. http://dx.doi. org/10.15560/7.4.496.

HABIB, M.E.M., PALEARI, M.L. and AMARAL, M.E.C., 1983. Effect of three larval diets on the development of the armyworm, Spodoptera latifascia (Walker, 1856) (Lepidoptera: Noctuidae). Revista Brasileira de Zoologia, vol. 1, no. 3, pp. 177-182. http:// dx.doi.org/10.1590/S0101-81751982000300007.

HOFFMANN-CAMPO, C.B., OLIVEIRA, E.B. and MOSCARDI, F., 1985. Criação massal da lagarta da soja (Anticarsia gemmatalis). Londrina: Embrapa-CNPSo, 23 p. Documentos, no. 10.

KEHAT, M. and GORDON, D., 1975. Mating, longevity, fertility and fecundity of the cotton leaf-worm, Spodoptera littoralis (Boisd.) (Lepidoptera: Noctuidae). Phytoparasitica, vol. 3, no. 2, pp. 87-102. http://dx.doi.org/10.1007/BF03158291.

MILANO, P., BERTI FILHO, E., PARRA, J.R.P. and CONSOLI, F.L., 2008. Influência da temperatura na frequência de cópula de Anticarsia gemmatalis (Hübner) e Spodoptera Frugiperda (J.E. Smith) (Lepidoptera: Noctuidae). Neotropical Entomology, vol. 37 , no. 5, pp. 528-535. http://dx.doi.org/10.1590/S1519566X2008000500005. PMid:19061037.

MONTEZANO, D.G., SOSA-GÓMEZ, D.R., PAULA-MORAES, S.V., ROQUE-SPECHT, V.F., FRONZA, E., BARROS, N.M. and SPECHT, A., 2016. Immature Development of Spodoptera dolichos (Fabricius) (Lepidoptera: Noctuidae). Neotropical Entomology, vol. 45, no. 1, pp. 22-27. http://dx.doi.org/10.1007/ s13744-015-0333-2. PMid:26429580.

MONTEZANO, D.G., SOSA-GÓMEZ, D.R., PAULA-MORAES, S.V., ROQUE-SPECHT, V.F., FRONZA, E., BARROS, N.M. and SPECHT, A., 2015. Biotic potential and reproductive parameters of Spodoptera dolichos (Fabricius, 1794) (Lepidoptera: Noctuidae), in the laboratory. Zoologia, vol. 32, no. 6, pp. 485-491. http:// dx.doi.org/10.1590/s1984-46702015000600008. 
MONTEZANO, D.G., SPECHT, A., BORTOLIN, T.M., FRONZA, E., SOSA-GÓMEZ, D.R., ROQUE-SPECHT, V.F., PEZZI, P.P., LUZ, P.C. and BARROS, N.M., 2013a. Immature stages of Spodoptera albula (Walker) (Lepidoptera: Noctuidae): Developmental parameters and host plants. Anais da Academia Brasileira de Ciências, vol. 85, no. 1, pp. 271-284. http://dx.doi. org/10.1590/S0001-37652013000100013. PMid:23538960.

MONTEZANO, D.G., SPECHT, A., SOSA-GÓMEZ, D.R., ROQUE-SPECHT, V.F. and BARROS, N.M., 2013b. Biotic potential and reproductive parameters of Spodoptera eridania (Stoll) (Lepidoptera, Noctuidae) in the laboratory. Revista Brasileira de Entomologia, vol. 57, no. 3, pp. 340-345. http:// dx.doi.org/10.1590/S0085-56262013005000026.

MONTEZANO, D.G., SPECHT, A., SOSA-GÓMEZ, D.R., ROQUE-SPECHT, V.F., BORTOLIN, T.M., FRONZA, E., PEZZI, P.P., LUZ, P.C. and BARROS, N.M., 2014a. Biotic potential, fertility and life table of Spodoptera albula (Walker) (Lepidoptera: Noctuidae), under controlled conditions. Anais da Academia Brasileira de Ciências, vol. 86, no. 2, pp. 723-732. http://dx.doi.org/10.1590/0001-3765201402812.

MONTEZANO, D.G., SPECHT, A., SOSA-GÓMEZ, D.R., ROQUE-SPECHT, V.F. and BARROS, N.M., 2014b. Immature stages of the armyworm, Spodoptera eridania: developmental parameters and host plants. Journal of Insect Science, vol. 14, no. 238, pp. 1-11. http://dx.doi.org/10.1093/jisesa/ieu100. PMid:25373148

MURÚA, M.G. and VIRLA, E., 2004. Population parameters of Spodoptera frugiperda (Smith) (Lep.: Noctuidae) fed on corn and two predominant grasses in Tucuman (Argentina). Acta Zoológica Mexicana, vol. 20, no. 1, pp. 199-210.

MURÚA, M.G., VERA, M.T., ABRAHAM, S., JUARÉZ, M.L., PRIETO, S., HEAD, G.P. and WILLINK, E., 2008. Fitness and mating compatibility of Spodoptera frugiperda (Lepidoptera: Noctuidae) populations from different host plant species and regions in Argentina. Annals of the Entomological Society of America, vol. 101, no. 3, pp. 639-649. http://dx.doi. org/10.1603/0013-8746(2008)101[639:FAMCOS]2.0.CO;2.

POGUE, G.M., 2002. A world revision of the genus Spodoptera Guenée (Lepidoptera: Noctuidae). Memoirs of the American Entomological Society, vol. 43, pp. 1-202.

POOLE, R.W., 1989. Noctuidae. In: J.B. HEPPNER, ed. Lepidopterorum Catalogus. New York: Brill, vol. 2, pp. 501-1014.

ROGERS, C.E. and MARTI JUNIOR, O.G., 1994. Reproductive potential of once mated moths of the fall armyworm (Lepidoptera: Noctuidae). The Florida Entomologist, vol. 77, no. 4, pp. 402-410. http://dx.doi.org/10.2307/3495694.

ROGERS, C.E. and MARTI JUNIOR, O.G., 1997. Once-mated beet armyworm (Lepidoptera: Noctuidae): effects of age at mating on fecundity, fertility, and longevity. Environmental Entomology, vol. 26, no. 3, pp. 585-590. http://dx.doi.org/10.1093/ee/26.3.585.

SADEK, M.M. and ANDERSON, P., 2007. Modulation of reproductive behavior of Spodoptera littoralis by host and nonhost plant leaves. Basic and Applied Ecology, vol. 8, no. 5, pp. 444-452. http://dx.doi.org/10.1016/j.baae.2006.08.001.

SADEK, M.M., 2001. Polyandry in field collected Spodoptera littoralis moths and laboratory assessment of the effects of male mating history. Entomologia Experimentalis et Applicata, vol. 98 , no. 2, pp. 165-172. http://dx.doi.org/10.1046/j.15707458.2001.00771.x
SANTOS, G.P., COSENZA, G.W. and ALBINO, J.C., 1980. Biologia de Spodoptera latifascia (Walker, 1856) (Lepidoptera: Noctuidae) sobre folhas de eucalipto. Revista Brasileira de Entomologia, vol. 24, no. 2, pp. 153-155.

SILVAIN, J. and LALANNE-CASSOU, B., 1997. Distinction entre Spodoptera latifascia (Walker) et Spodoptera cosmioides (Walker), bona species (Lepidoptera, Noctuidae). Revue Francaise d'Entomologie, vol. 19, no. 3-4, pp. 95-97.

SILVEIRA-NETO, S., NAKANO, O., BARBIN, D. and VILLA NOVA, N.A., 1976. Manual de ecologia dos insetos. São Paulo: Editora Agronômica Ceres, 420 p.

SOROUR, M.A., KHAMISS, O., EL-WAHAB, A.S.E., ELSHEIKH, M.A.K. and ABUL-ELA, S., 2011. An economically modified semi-synthetic diet for mass rearing the Egyptian cotton leaf worm Spodoptera littoralis. Academic Journal of Entomology, vol. 4 , no. 3, pp. 118-123.

SPECHT, A. and CORSEUIL, E., 2002. Diversidade dos noctuídeos (Lepidoptera, Noctuidae) em Salvador do Sul, Rio Grande do Sul, Brasil. Revista Brasileira de Zoologia, vol. 19, suppl. 1, pp. 281-298. http://dx.doi.org/10.1590/S0101-81752002000500022.

SPECHT, A. and ROQUE-SPECHT, V.F., 2016. Immature stages of Spodoptera cosmioides (Lepidoptera: Noctuidae): developmental parameters and host plants. Zoologia, vol. 33, no. 4, pp. 1-10. http://dx.doi.org/10.1590/S1984-4689zool-20160053.

SPECHT, A., MONTEZANO, D.G., SOSA-GÓMEZ, D.R., PAULA-MORAES, S.V., ROQUE-SPECHT, V.F. and BARROS, N.M., 2016. Reproductive potential of Spodoptera eridania (Stoll) (Lepidoptera: Noctuidae) in the laboratory: effect of multiple couples and the size. Brazilian Journal of Biology $=$ Revista Brasileira de Biologia, vol. 76, no. 2, pp. 526-530. http://dx.doi. org/10.1590/1519-6984.23114. PMid:26959952.

SPECHT, A., TESTON, J.A., DI MARE, R.A. and CORSEUIL, E., 2005. Noctuídeos (Lepidoptera, Noctuidae) coletados em quatro Áreas Estaduais de Conservação do Rio Grande do Sul, Brasil. Revista Brasileira de Entomologia, vol. 49, no. 1, pp. 130-140. http://dx.doi.org/10.1590/S0085-56262005000100015.

TEIXEIRA, A.L., OLIVEIRA, J.S. and VILELA, E.F., 1993. (Z)-11-hexadecenyl acetate, a new sex pheromone component of Spodoptera latifascia Walker (Lepidoptera: Noctuidae). Revista Ceres, vol. 40, no. 229, pp. 230-234

TEIXEIRA, A.L., OLIVEIRA, J.S., VILELA, E.F., LIMA, E.R. and REIS, H.O., 1989. Sex pheromone components of Spodoptera latifascia Walker (Lepidoptera: Noctuidae). Revista Ceres, vol. 36, no. 206, pp. 373-381

TISDALE, R.A. and SAPPINGTON, T.W., 2001. Realized and potential fecundity, egg fertility, and longevity of laboratory-reared female beet armyworm (Lepidoptera: Noctuidae) under different adult diet regimes. Annals of the Entomological Society of America, vol. 94, no. 3, pp. 415-419. http://dx.doi.org/10.1603/00138746(2001)094[0415:RAPFEF]2.0.CO;2.

ZENKER, M.M., BOTTON, M., TESTON, J.A. and SPECHT, A., 2010. Noctuidae moths occurring in grape orchards in Serra Gaúcha, Brazil and their relation to fruit-piercing. Revista Brasileira de Entomologia, vol. 54, no. 2, pp. 288-297. http:// dx.doi.org/10.1590/S0085-56262010000200012.

ZENKER, M.M., SPECHT, A. and CORSEUIL, E., 2007. Estágios imaturos de Spodoptera cosmioides (Walker) (Lepidoptera, Noctuidae). Revista Brasileira de Zoologia, vol. 24, no. 1, pp. 99-107. http://dx.doi.org/10.1590/S0101-81752007000100013. 